\title{
PENGARUH BIG-FIVE PERSONALITY DAN ENVIRONMENTAL SENSITIVITY TERHADAP RESPONSIBLE ENVIRONMENTAL BEHAVIOR SISWA
}

\author{
Ade Imas Rismayati ${ }^{1}$, I Made Putrawan², Diana Vivanti Sigit ${ }^{3}$ \\ ${ }^{1}$ Student of Biology Education Departement of State University of Jakarta \\ ${ }^{2}$ Environmental Education Departement of State University of Jakarta \\ ${ }^{3}$ Biology Education Departement of State University of Jakarta \\ Email : adeimasrismayati@gmail.com,putrawan.imade@yahoo.com, \\ dianavivanti@yahoo.com
}

\begin{abstract}
Environmental problem is a problem that must be solved by all parties, including students. Responsible environmental behavior arises from awareness of environmental issues. This awareness led to intention and determination of student to set their attitude and behavior towards the problems they faced. Responsible environmental behavior is basically the result of interaction between various factors. Factors that may affect the responsibilities behavior among the personality and the environmental sensitivity. This study aims to determine the effect of personality and environmental sensitivity on the responsible environmental behavior that students have. Research conducted at SMA Labschool Jakarta on the Semester I of 2018/2019 school year. The method used is the survey with quantitative-causal causal approach and path analysis. The sample were 79 students of class XI MIPA. Based on hypothesis test, the value of the path coefficient of $X_{1}$ to $X_{2}$ is 0.495 , path coefficient $\mathrm{X}_{2}$ to $\mathrm{X}_{3}$ is 0.028 , and path coefficient $\mathrm{X}_{1}$ to $\mathrm{X}_{3}$ is 0.568 but the path coefficient $X_{1}$ to $\mathrm{X}_{3}$ through $\mathrm{X}_{2}$ cannot be calculated. Based on these results, it can be concluded that environmental sensitivity is not suitable as a mediator of variables between personality and responsible environmental behavior.
\end{abstract}

Keywords: Personality, environmental sensitivity, responsible environmental behavior.

\begin{abstract}
ABSTRAK
Masalah lingkungan merupakan masalah yang harus diselesaikan oleh semua pihak, termasuk siswa. Perilaku tanggung jawab lingkungan timbul dari kesadaran akan permasalahan yang sering terjadi. Kesadaran inilah yang memunculkan niat dan tekad siswa untuk menentukan sikap dan perilaku terhadap masalah yang dihadapi. Perilaku tanggung jawab lingkungan yang dimiliki siswa merupakan hasil interaksi antara berbagai faktor. Faktor tersebut diantaranya adalah kepribadian dan sensitivitas lingkungan. Penelitian ini bertujuan untuk mengetahui pengaruh kepribadian dan sensitivitas lingkungan terhadap perilaku tanggung jawab lingkungan siswa. Penelitian dilaksanakan di SMA Labschool Jakarta pada Semester I Tahun Ajaran 2018/2019. Metode yang digunakan adalah metode survei melalui studi kausal dan dianalisis dengan analisis jalur. Sampel yang digunakan berjumlah 79 siswa kelas XI MIPA. Hasil pengujian hipotesis diperoleh koefisien jalur $\mathrm{X}_{1}$ terhadap $\mathrm{X}_{2}$ sebesar 0,495, koefisien jalur $\mathrm{X}_{2}$ terhadap $\mathrm{X}_{3}$ sebesar 0.028, dan koefisien jalur $\mathrm{X}_{1}$ terhadap $\mathrm{X}_{3}$ sebesar 0,568 tetapi koefisien jalur $X_{1}$ terhadap $X_{3}$ melalui $X_{2}$ tidak dapat dihitung. Berdasarkan hasil tersebut, dapat disimpulkan bahwa sensitivitas lingkungan tidak cocok sebagai mediator variabel antara kepribadian dengan perilaku tanggung jawab lingkungan.
\end{abstract}

Kata Kunci: Kepribadian, sensitivitas lingkungan, perilaku tanggung jawab lingkungan. 


\section{PENDAHULUAN}

Responsible environmental behavior adalah aktivitas seseorang dalam kehidupan sehari-hari terutama pola perilaku interaksinya dengan lingkungan (Id, Chou, Morrison, \& Lin, 2018). Sesuai dengan model perilaku lingkungan Hines, responsible environmental behavior dapat disebabkan oleh faktor situasional, faktor personality, dan keinginan untuk bertindak. Menurut Hines, Hungerford \& Tomera (1987) faktor situasional dipengaruhi oleh pandangan individu akan suatu hal, sedangkan keinginan bertindak dipengaruhi oleh personality.

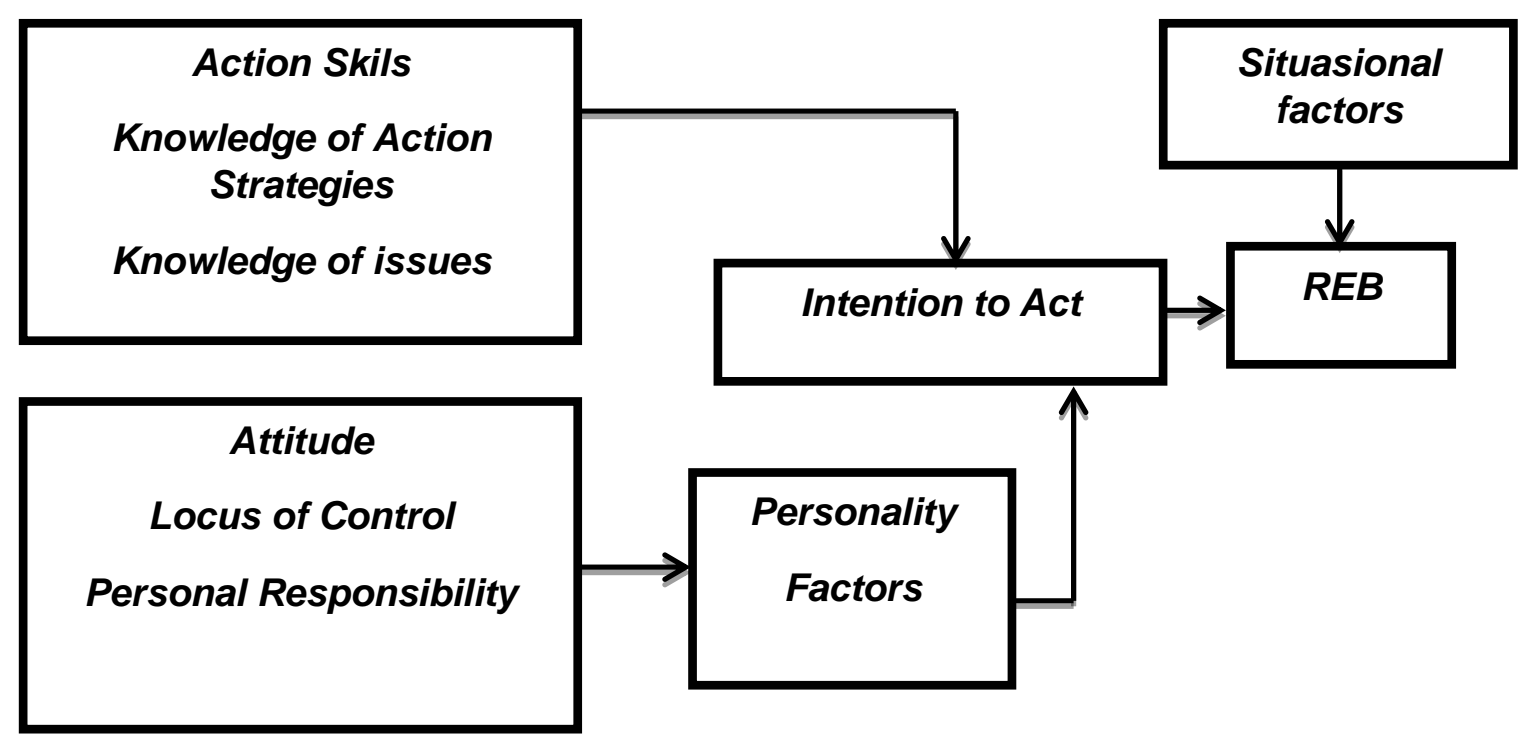

Gambar 1. Model Perilaku yang Menggambarkan Pembentukan Responsible Environmental Behavior (Hines, Hungerford, \& Tomera, 2010)

Responsible environmental behavior dijelaskan sebagai hubungan di mana peningkatan pengetahuan individu menyebabkan tindakan yang menguntungkan terhadap lingkungan. Responsible environmental behavior adalah perilaku perhatian individu terhadap lingkungan, komitmen dan pengetahuan ekologis. Responsible environmental behavior dianggap sebagai suatu usaha perlindungan lingkungan sesuai dengan norma-norma yang sesuai (Handriana \& Ambara, 2016)

Van Liere dan Dunlap (1984), memandang responsible environmental behavior sebagai ekspresi atau dimensi kepedulian lingkungan yang terdiri dari kegiatan yang mengusulkan bagaimana individu memecahkan masalah lingkungan. Responsible environmental behavior dijelaskan sebagai hubungan di mana peningkatan pengetahuan sikap yang menguntungkan pada gilirannya menyebabkan tindakan yang menguntungkan terhadap 
lingkungan (Ramsey, Hungerford, and Tomera, 1981). Menurut Krajhanzl (2010), responsible environmental behavior dipengaruhi oleh tiga faktor yaitu (1) condition factors (external factors), (2) personality factors dan (3) relationship to nature factors.

Personality adalah sifat seseorang yang dinamis dalam merespon dan bereaksi serta berinteraksi yang relatif stabil dengan orang lain atau lingkungannya sesuai dengan dimensi big-five personality, yaitu conscientiousness, agreeableness, neuroticism, openness, extraversion dalam rangka mencapai tujuan (Laraga, 2017). Personality merupakan kumpulan beberapa ciri-ciri antara lain seperti bertanggung jawab, sopan, dan pendiam yang menggambarkan diri seseorang (Laraga, 2017).

McCrae dan Costa (2009) mengukur big five personality dengan kuisioner NEOpersonality inventory revised seperti tabel di bawah ini:

Tabel 1. Lima Model Kepribadian Costa dan McCrae

\begin{tabular}{|ll|}
\hline Openness (O) & Fantasy, Aesthetics, Feelings, Actions, Ideas, Values \\
\hline Conscientiousness (C) & $\begin{array}{l}\text { Competence, Order, Dutifulness, Achievement, Striving, Self-discipline, } \\
\text { Deliberation }\end{array}$ \\
\hline Extraversion (E) & $\begin{array}{l}\text { Warmth, Gregariousness, Assertiveness, Activity, Excitement-seeking, } \\
\text { Positive Emotions }\end{array}$ \\
\hline Agreebleness (A) & $\begin{array}{l}\text { Trust, Straightforwardness, Alturism, Compliance, Modesty, Tender- } \\
\text { mindedness }\end{array}$ \\
\hline Neuroticism (N) & $\begin{array}{l}\text { Anxiety, Angry Hostility, Depression, Self-consciousness, Impulsiveness, } \\
\text { Vulnerability }\end{array}$ \\
\hline
\end{tabular}

Personality mampu memengaruhi tingkat environmental sensitivity seseorang terhadap lingkungan sehingga seseorang dengan personality baik akan meningkatkan environmental sensitivity dirinya terhadap lingkungan sehingga dapat mencerminkan pula responsible environmental behavior.

Id, Chou, Morrison, \& Lin (2018) mengemukakan bahwa personality seseorang secara signifikan mempengaruhi environmental sensitivity. Environmental Sensitivity dapat diartikan sebagai sifat seseorang yang mengacu pada perbedaan respon terhadap kondisi lingkungan (Nadiroh, 2011). Menurut Chawla (2010) environmental sensitivity dapat diartikan sebagai sifat empati individu terhadap lingkungan dan mengklasifikasikannya sebagai variabel penting dari kesadaran lingkungan serta dalam bentuk untuk mempraktekkan perilaku lingkungan. Sivek and Hungerford (2014) menyatakan bahwa pengetahuan lingkungan dapat 
mempengaruhi sensitivitas lingkungan seseorang, dan pengetahuan lingkungan dan kepekaan lingkungan dapat meningkatkan tingkat perilaku lingkungan.

Personality dan environmental sensitivity memberikan gambaran terhadap perilaku seseorang terhadap lingkungan. Personality membuat seseorang berperilaku menjadi dirinya sendiri tanpa terpengaruh oleh orang lain dan environmental sensitivity yang dimiliki seseorang akan sesuai dengan personality yang ia miliki sehingga akan tercermin responsible environmental behavior seseorang.

Berdasarkan uraian di atas, maka rumusan masalah pada penelitian ini adalah: (1) apakah personality berpengaruh langsung terhadap environmental sensitivity siswa?; (2) apakah environmental sensitivity berpengaruh langsung terhadap responsible environmental behavior siswa?; (3) apakah personality berpengaruh langsung terhadap responsible environmental behavior siswa?; dan (4) apakah personality berpengaruh tidak langsung terhadap responsible environmental behavior melalui environmental sensitivity siswa?. Penelitian ini bertujuan untuk mengetahui pengaruh personality dan environmental sensitivity terhadap responsible environmental behavior yang dimiliki siswa.

\section{METODOLOGI PENELITIAN}

Metode penelitian yang digunakan adalah metode survei yang bersifat kausal. Penelitian ini termasuk kedalam jenis penelitian kuantitatif dengan menggunakan analisis jalur (path analysis) yang dipilih untuk menganalisis pola hubungan antar variabel dengan tujuan untuk mengetahui pengaruh secara langsung maupun tidak langsung antara variabel eksogen dan endogen. Penelitian ini mempunyai tiga variabel, yaitu X1 (personality) dan X2 (environmental sensitivity) sebagai variabel eksogen serta X3 (responsible environmental behavior) sebagai variabel endogen. Model dari penelitian ini dapat digambarkan sebagai berikut:

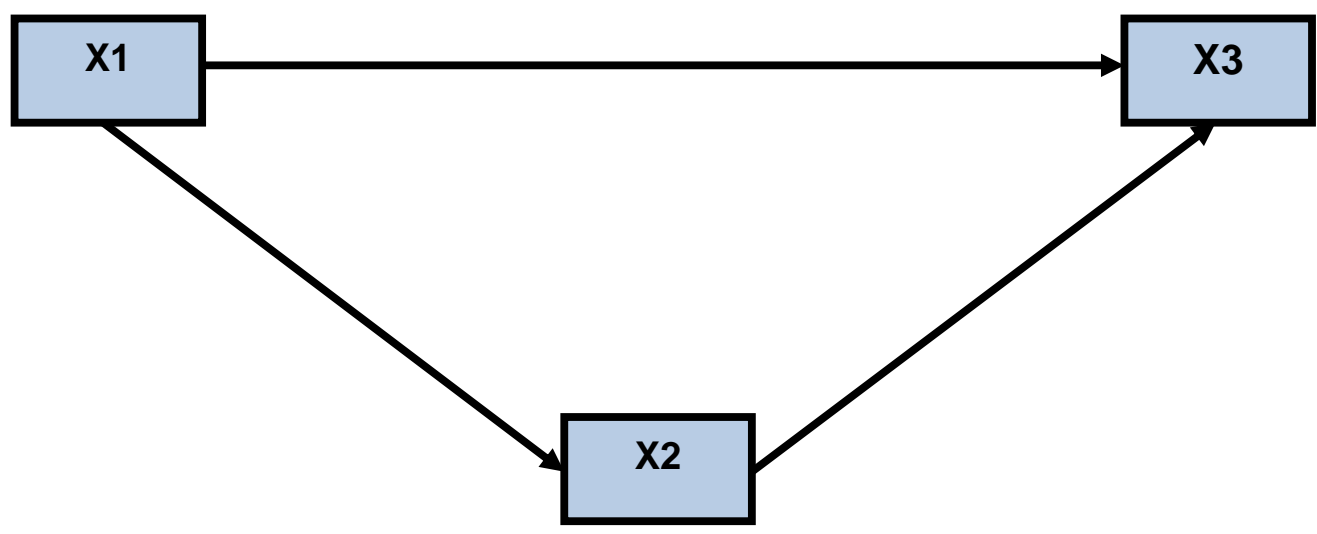




\section{Gambar 2. Model Path Analiysis}

Dalam penelitian ini populasinya adalah seluruh siswa SMA kelas XI IPA di Provinsi DKI Jakarta. Penentuan sampel dalam penelitian ini menggunakan teknik pemilihan sampel bertingkat (multi stage sampling) dengan tahapan sebagai berikut:

Pertama, dengan menggunakan teknik purposive sampling dipilih Jakarta Timur. Kedua, dengan menggunakan teknik cluster random sampling dari seluruh kecamatan di wilayah Jakarta Timur terpilih kecamatan Pulogadung. Ketiga, dengan menggunakan teknik cluster random sampling dari seluruh SMA di kecamatan Pulogadung terpilih SMA Labschool Jakarta sebagai tempat penelitian. Keempat, karena populasi penelitain adalah seluruh siswa SMA kelas XI IPA maka secara simple random sampling terpilihlah tiga kelas dengan jumlah 80 siswa kelas XI IPA di sekolah SMA Labschool Jakarta yang dijadikan sebagai responden dalam penelitian. Selanjutnya 79 siswa dari 80 siswa terpilih sebagai sampel menggunakan teknik simple random sampling. Pengumpulan data untuk mengetahui personality, environmental sensitivity, dan responsible environmental behavior siswa dilakukan dengan menyebarkan instrumen berupa opinioner.

\section{HASIL DAN PEMBAHASAN}

Hasil perhitungan mengenai keberartian dan kelinieran regresi dilakukan dengan menggunakan uji $\mathrm{F}$, dan hasilnya diuraikan sebagai berikut:

\section{a) Environmental Sensitivity $\left(\mathrm{X}_{2}\right)$ atas Personality $\left(\mathrm{X}_{1}\right)$}

Dari data hasil perhitungan untuk penyusunan model persamaan regresi environmental sensitivity $\left(\mathrm{X}_{2}\right)$ atas personality $\left(\mathrm{X}_{1}\right)$, diperoleh konstanta regresi a $=71.369$ dan koefisien regresi $b=0.477$. Dengan demikian hubungan model persamaan regresi sederhana adalah $\dot{X}_{2}=71.369+0.477 \mathrm{X}_{1}$. Sebelum model persamaan regresi dianalisis lebih lanjut, terlebih dahulu dilakukan uji signifikansi dan linearitas persamaan model regresi.

\section{1) Pengujian Signifikansi Persamaan Regresi}

Pengujian signifikansi regresi menggunakan uji ANAVA regresi dari setiap variabel yang diukur. Hasil pengujian regresi signifikansi environmental sensitivity $\left(\mathrm{X}_{2}\right)$ atas personality $\left(\mathrm{X}_{1}\right)$ disajikan dalam tabel 1. berikut ini: 
Tabel 1. ANAVA Regresi Signifikansi $\left(X_{2}\right.$ atas $\left.X_{1}\right)$

\begin{tabular}{|c|c|c|c|c|c|c|}
\hline \multicolumn{7}{|c|}{ ANOVA $^{a}$} \\
\hline Model & & $\begin{array}{l}\text { Sum of } \\
\text { Squares }\end{array}$ & Df & $\begin{array}{c}\text { Mean } \\
\text { Square }\end{array}$ & $\mathrm{F}$ & Sig. \\
\hline \multirow{3}{*}{1} & Regression & 3.280 .492 & 1 & 3.280 .492 & 24.927 & $.000^{\mathrm{b}}$ \\
\hline & Residual & 10.133 .660 & 77 & 131.606 & & \\
\hline & Total & 13.414 .152 & 78 & & & \\
\hline \multicolumn{7}{|c|}{ a. Dependent Variable: ES } \\
\hline b. Predictors: ( & nstant), Per & & & & & \\
\hline
\end{tabular}

Untuk pengujian signifikansi regresi diperoleh $F_{\text {hitung }}$ sebesar 24.927 sedangkan $F_{\text {tabel }}$ $(\alpha=0.01)(1 / 77)$ sebesar 6.96 sehingga $F_{\text {hitung }}>F_{\text {tabel. }}$ Ini memberikan arti bahwa persamaan regresi $\dot{\mathrm{X}}_{2}=71.369+0.477 \mathrm{X}_{1}$ adalah signifikan.

\section{2) Pengujian Linearitas Persamaan Regresi}

Pengujian linearitas menggunakan uji ANAVA regresi dari setiap variabel yang diukur. Hasil pengujian linearitas regresi environmental sensitivity $\left(\mathrm{X}_{2}\right)$ atas personality $\left(\mathrm{X}_{1}\right)$ disajikan dalam tabel 2. berikut ini:

Tabel 2. ANAVA Regresi Linear $\left(X_{2} \operatorname{atas} X_{1}\right)$

\begin{tabular}{|c|c|c|c|c|c|c|c|}
\hline \multicolumn{8}{|c|}{ ANOVA Table } \\
\hline & & & $\begin{array}{c}\text { Sum of } \\
\text { Squares }\end{array}$ & df & $\begin{array}{c}\text { Mean } \\
\text { Square }\end{array}$ & $\mathbf{F}$ & Sig. \\
\hline \multirow{5}{*}{$\mathrm{X} 2 * \mathrm{X} 1$} & \multirow{3}{*}{$\begin{array}{l}\text { Between } \\
\text { Groups }\end{array}$} & (Combined) & 6.874 .890 & 34 & 202.203 & 1.361 & .167 \\
\hline & & Linearity & 3.280 .492 & 1 & 3.280 .492 & 22.073 & .000 \\
\hline & & $\begin{array}{l}\text { Deviation from } \\
\text { Linearity }\end{array}$ & 3.594 .398 & 33 & 108.921 & .733 & .822 \\
\hline & \multicolumn{2}{|c|}{ Within Groups } & 6.539 .262 & 44 & 148.620 & & \\
\hline & \multicolumn{2}{|l|}{ Total } & 13.414 .152 & 78 & & & \\
\hline
\end{tabular}


Untuk pengujian linearitas regresi diperoleh $F_{\text {hitung }}$ sebesar 0.733 sedangkan $F_{\text {tabel }}$ $(\alpha=0.01)(33 / 44)$ sebesar 2.09 sehingga $F_{\text {hitung }}<F_{\text {tabel. }}$ Ini memberikan arti bahwa persamaan regresi $\dot{\mathrm{X}}_{2}=71.369+0.477 \mathrm{X}_{1}$ adalah linier. Secara visual dapat dilihat pada Gambar 3 .

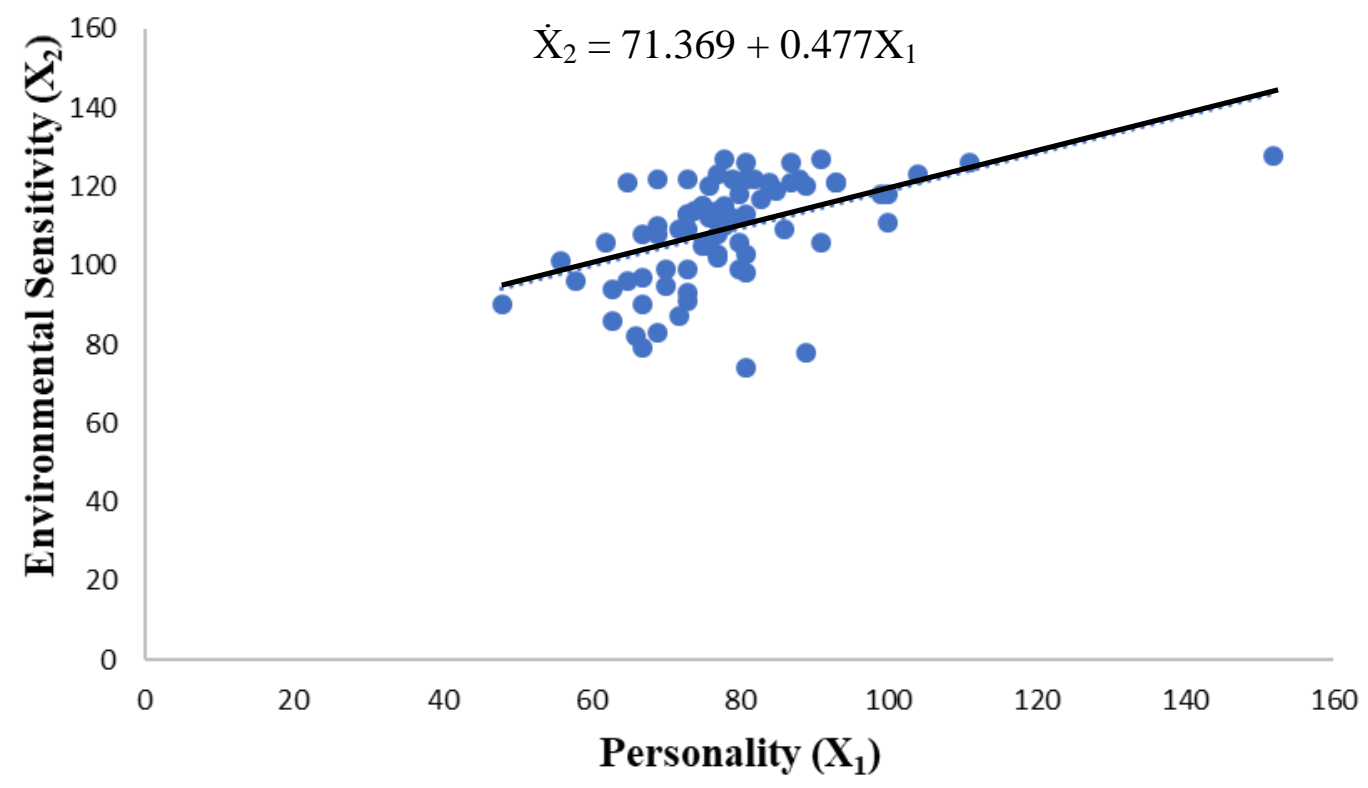

Gambar 3. Grafik Persamaan Regresi $\dot{\mathrm{X}}_{2}=71.369+0.477 \mathrm{X}_{1}$

\section{3) Pengujian Koefisien Korelasi}

Hasil perhitungan koefisien korelasi $X_{2}$ atas $X_{1}$ dengan bantuan komputer SPSS ver. 20 dapat dilihat pada tabel 3. Berikut:

Tabel 3. Output SPSS Koefisien Korelasi $X_{2}$ atas $X_{1}$

\begin{tabular}{|c|c|c|c|}
\hline \multicolumn{4}{|c|}{ Correlations } \\
\hline & & ES & Personality \\
\hline \multirow{2}{*}{ Pearson Correlation } & ES & 1.000 & .495 \\
\hline & Personality & .495 & 1.000 \\
\hline \multirow{2}{*}{ Sig. (1-Tailed) } & $\mathrm{ES}$ & & .000 \\
\hline & Personality & .000 & . \\
\hline \multirow{2}{*}{$\mathrm{N}$} & ES & 79 & 79 \\
\hline & Personality & 79 & 79 \\
\hline
\end{tabular}

b) Responsible Environmental Behavior $\left(\mathrm{X}_{3}\right)$ atas Environmental Sensitivity $\left(\mathrm{X}_{2}\right)$ 
Dari data hasil perhitungan untuk penyusunan model persamaan regresi responsible environmental behavior $\left(\mathrm{X}_{3}\right)$ atas environmental sensitivity $\left(\mathrm{X}_{2}\right)$, diperoleh konstanta regresi $\mathrm{a}=37.680$ dan koefisien regresi $\mathrm{b}=0.288$. Dengan demikian hubungan model persamaan regresi sederhana adalah $\dot{X}_{3}=37.680+0.288 X_{2}$. Sebelum model persamaan regresi dianalisis lebih lanjut, terlebih dahulu dilakukan uji signifikansi dan linearitas persamaan model regresi.

\section{1) Pengujian Signifikansi Persamaan Regresi}

Pengujian signifikansi regresi menggunakan uji ANAVA regresi dari setiap variabel yang diukur. Hasil uji signifikansi regresi responsible environmental behavior $\left(\mathrm{X}_{3}\right)$ atas environmental sensitivity $\left(\mathrm{X}_{2}\right)$ disajikan dalam tabel 4. berikut inI:

Tabel 4. ANAVA Regresi Signifikansi $\left(X_{3}\right.$ atas $\left.X_{2}\right)$

\begin{tabular}{|c|c|c|c|c|c|c|}
\hline \multicolumn{7}{|c|}{$\mathrm{ANOVA}^{\mathrm{a}}$} \\
\hline Model & & Sum of Squares & Df & Mean Square & $\mathrm{F}$ & Sig. \\
\hline \multirow{3}{*}{1} & Regression & 1111.750 & 1 & 1111.750 & 8.126 & $.006^{\mathrm{b}}$ \\
\hline & Residual & 10534.047 & 77 & 136.806 & & \\
\hline & Total & 11645.797 & 78 & & & \\
\hline \multicolumn{7}{|c|}{ a. Dependent Variable: REB } \\
\hline b. Pred & ctors: (Constant), ES & & & & & \\
\hline
\end{tabular}

Untuk pengujian signifikansi regresi diperoleh $F_{\text {hitung }}$ sebesar 8.126 sedangkan $F_{\text {tabel }}$ $(\alpha=0.01)(1 / 77)$ sebesar 6.96 sehingga $F_{\text {hitung }}>F_{\text {tabel. }}$ Ini memberikan arti bahwa persamaan regresi $\dot{\mathrm{X}}_{3}=37.680+0.288 \mathrm{X}_{2}$ adalah signifikan.

\section{2) Pengujian Linearitas Persamaan Regresi}

Pengujian linearitas menggunakan uji ANAVA regresi dari setiap variabel yang diukur. Hasil pengujian linearitas regresi responsible environmental behavior $\left(\mathrm{X}_{3}\right)$ atas environmental sensitivity $\left(\mathrm{X}_{2}\right)$ disajikan dalam tabel 5. berikut ini:

Tabel 5. ANAVA Regresi Linear $\left(X_{3}\right.$ atas $\left.X_{2}\right)$

\begin{tabular}{|c|c|c|c|c|c|c|c|}
\hline \multicolumn{8}{|c|}{ ANOVA Table } \\
\hline & & & $\begin{array}{l}\text { Sum of } \\
\text { Squares }\end{array}$ & Df & $\begin{array}{l}\text { Mean } \\
\text { Square }\end{array}$ & $\mathrm{F}$ & Sig. \\
\hline \multirow{5}{*}{$\mathrm{X} 3 * \mathrm{X} 2$} & \multirow{3}{*}{$\begin{array}{l}\text { Between } \\
\text { Groups }\end{array}$} & (Combined) & 6.013 .681 & 38 & 158.255 & 1.124 & .357 \\
\hline & & Linearity & 1.111 .750 & 1 & 1.111 .750 & 7.896 & .008 \\
\hline & & $\begin{array}{l}\text { Deviation from } \\
\text { Linearity }\end{array}$ & 4.901 .931 & 37 & 132.485 & .941 & .573 \\
\hline & \multicolumn{2}{|c|}{ Within Groups } & 5.632 .117 & 40 & 140.803 & & \\
\hline & \multicolumn{2}{|c|}{ Total } & 11.645 .797 & 78 & & & \\
\hline
\end{tabular}


Untuk pengujian linearitas regresi diperoleh $F_{\text {hitung }}$ sebesar 0.941 sedangkan $F_{\text {tabel }}$ $(\alpha=0.01)(37 / 40)$ sebesar 2.11 sehingga $F_{\text {hitung }}<F_{\text {tabel. }}$ Ini memberikan arti bahwa persamaan regresi $\dot{\mathrm{X}}_{3}=37.680+0.288 \mathrm{X}_{2}$ adalah linier. Secara visual dapat dilihat pada Gambar 4.

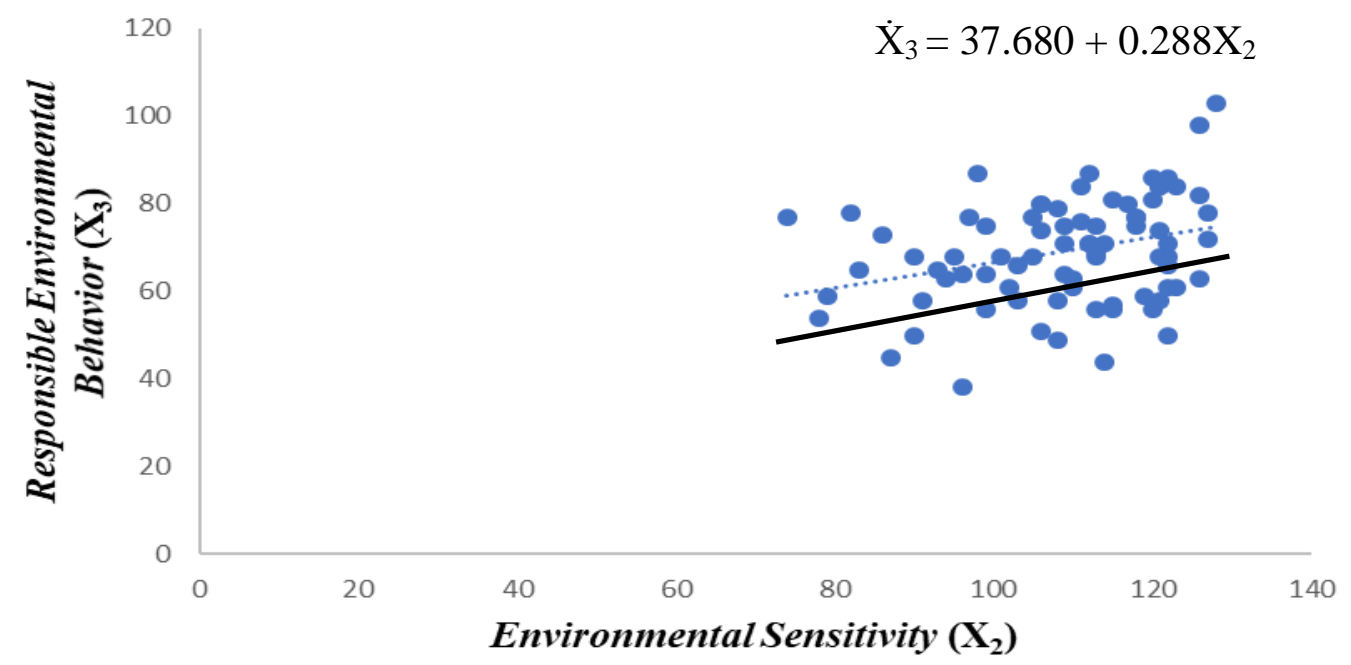

Gambar 4. Grafik Persamaan Regresi $\dot{X}_{3}=37.680+0.288 X_{2}$

\section{3) Pengujian Koefisien Korelasi}

Hasil perhitungan koefisien korelasi $\mathrm{X}_{3}$ atas $\mathrm{X}_{2}$ dengan bantuan komputer SPSS ver. 20 dapat dilihat pada tabel 6. berikut:

Tabel 6. Output SPSS Koefisien Korelasi $X_{3}$ atas $X_{2}$

\begin{tabular}{|c|c|c|c|c|}
\hline \multicolumn{5}{|c|}{ Correlations } \\
\hline & & REB & Personality & ES \\
\hline \multirow{3}{*}{ Pearson Correlation } & REB & 1.000 & .582 & .309 \\
\hline & Personality & .582 & 1.000 & 495 \\
\hline & ES & .309 & .495 & 1.000 \\
\hline \multirow{3}{*}{ Sig. (1-tailed) } & REB & & .000 & .003 \\
\hline & Personality & .000 & & .000 \\
\hline & ES & .003 & .000 & . \\
\hline \multirow{3}{*}{$\mathrm{N}$} & REB & 79 & 79 & 79 \\
\hline & Personality & 79 & 79 & 79 \\
\hline & ES & 79 & 79 & 79 \\
\hline
\end{tabular}

\section{c) Responsible Environmental Behavior $\left(\mathrm{X}_{3}\right)$ atas Personality $\left(\mathrm{X}_{1}\right)$}

Dari data hasil perhitungan untuk penyusunan model persamaan regresi responsible environmental behavior $\left(\mathrm{X}_{3}\right)$ atas personality $\left(\mathrm{X}_{1}\right)$, diperoleh konstanta regresi $\mathrm{a}=28.008$ dan koefisien regresi $b=0.523$. Dengan demikian hubungan model persamaan regresi 
sederhana adalah $\dot{X}_{3}=28.008+0.523 \mathrm{X}_{1}$. Sebelum model persamaan regresi dianalisis lebih lanjut, terlebih dahulu dilakukan uji signifikansi dan linearitas persamaan model regresi.

\section{1) Pengujian Signifikansi Persamaan Regresi}

Pengujian signifikansi regresi menggunakan uji ANAVA regresi dari setiap variabel yang diukur. Hasil pengujian signifikansi responsible environmental behavior $\left(\mathrm{X}_{3}\right)$ atas personality $\left(\mathrm{X}_{1}\right)$ disajikan dalam tabel 7. berikut ini:

Tabel 7. ANAVA Regresi Signifikansi $\left(\mathbf{X}_{3} \operatorname{atas} \mathbf{X}_{1}\right)$

\begin{tabular}{|c|c|c|c|c|c|c|}
\hline \multicolumn{7}{|c|}{ ANOVA $^{\mathbf{a}}$} \\
\hline \multicolumn{2}{|l|}{ Model } & $\begin{array}{l}\text { Sum of } \\
\text { Squares }\end{array}$ & $\mathrm{df}$ & $\begin{array}{l}\text { Mean } \\
\text { Square }\end{array}$ & $\mathrm{F}$ & Sig. \\
\hline \multirow{3}{*}{1} & Regression & 3.945 .541 & 1 & 3.945 .541 & 39.454 & $.000^{\mathrm{b}}$ \\
\hline & Residual & 7.700 .257 & 77 & 100.003 & & \\
\hline & Total & 11.645 .797 & 78 & & & \\
\hline \multicolumn{7}{|c|}{ a. Dependent Variable: REB } \\
\hline \multicolumn{7}{|c|}{ b. Predictors: (Constant), Personality } \\
\hline
\end{tabular}

Untuk pengujian signifikansi regresi diperoleh $F_{\text {hitung }}$ sebesar 39.454 sedangkan $F_{\text {tabel }}$ $(\alpha=0.01)(1 / 77)$ sebesar 6.96 sehingga $F_{\text {hitung }}>F_{\text {tabel. }}$ Ini memberikan arti bahwa persamaan regresi $\dot{\mathrm{X}}_{3}=28.008+0.523 \mathrm{X}_{1}$ adalah signifikan.

\section{2) Pengujian Linearitas Persamaan Regresi}

Pengujian linearitas menggunakan uji ANAVA regresi dari setiap variabel yang diukur. Hasil pengujian linearitas regresi responsible environmental behavior $\left(\mathrm{X}_{3}\right)$ atas personality $\left(\mathrm{X}_{1}\right)$ disajikan dalam tabel 8 . berikut ini:

Tabel 8. ANAVA Regresi Linear $\left(X_{3} \operatorname{atas} X_{1}\right)$

\begin{tabular}{|c|c|c|c|c|c|c|c|}
\hline \multicolumn{8}{|c|}{ ANOVA Table } \\
\hline & & & $\begin{array}{l}\text { Sum of } \\
\text { Squares }\end{array}$ & Df & Mean Square & $\mathrm{F}$ & Sig. \\
\hline \multirow{4}{*}{$\begin{array}{l}\mathrm{X} 3 * \\
\mathrm{X} 1\end{array}$} & \multirow{3}{*}{$\begin{array}{l}\text { Between } \\
\text { Groups }\end{array}$} & (Combined) & 7.739 .202 & 34 & 227.624 & 2.564 & .002 \\
\hline & & Linearity & 3.945 .541 & 1 & 3.945 .541 & 44.439 & .000 \\
\hline & & $\begin{array}{l}\text { Deviation from } \\
\text { Linearity }\end{array}$ & 3.793 .662 & 33 & 114.959 & 1.295 & .210 \\
\hline & \multicolumn{2}{|c|}{ Within Groups } & 3.906 .595 & 44 & 88.786 & & \\
\hline
\end{tabular}


Untuk pengujian linearitas regresi diperoleh $F_{\text {hitung }}$ sebesar 1.295 sedangkan $F_{\text {tabel }}$ $(\alpha=0.01)(33 / 44)$ sebesar 2.09 sehingga $F_{\text {hitung }}<F_{\text {tabel. }}$ Ini memberikan arti bahwa persamaan regresi $\dot{\mathrm{X}}_{3}=28.008+0.523 \mathrm{X}_{1}$ adalah linier. Secara visual dapat dilihat pada Gambar 5.

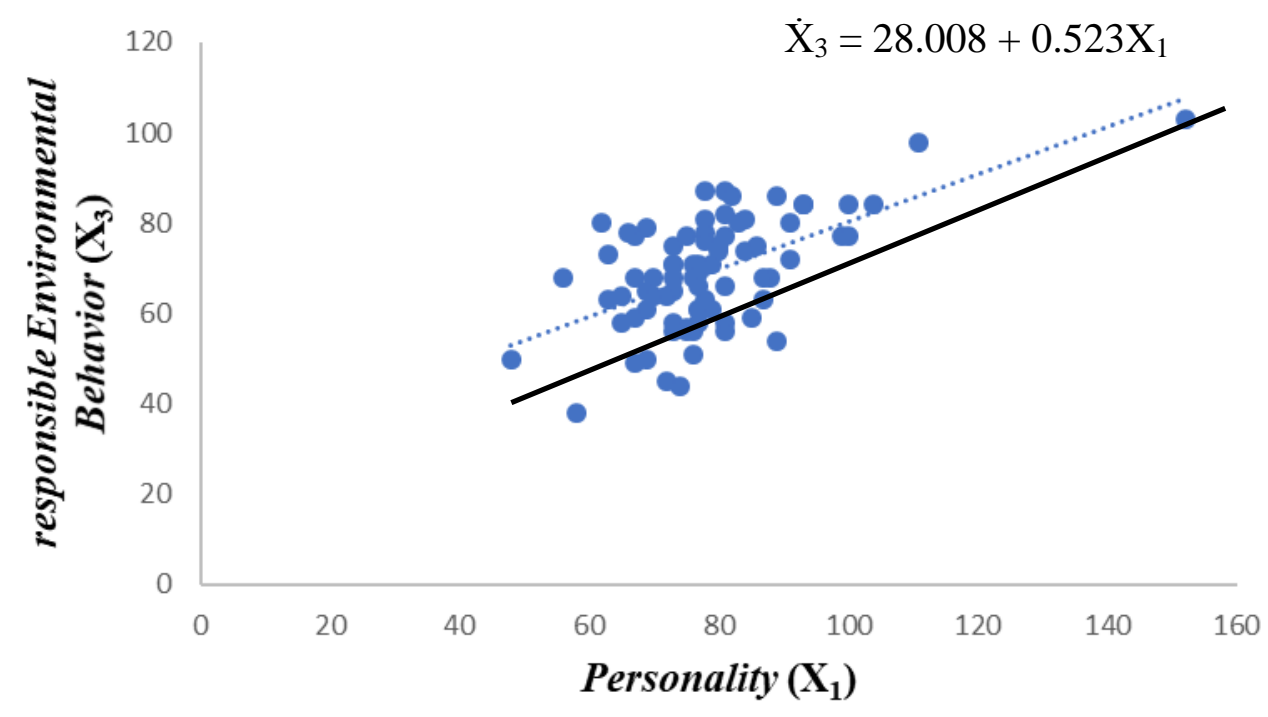

Gambar 5. Grafik Persamaan Regresi $\dot{X}_{3}=28.008+0.523 X_{1}$

\section{3) Pengujian Koefisien Korelasi}

Hasil perhitungan koefisien korelasi $X_{3}$ atas $X_{1}$ dengan bantuan komputer SPSS ver. 20 dapat dilihat pada tabel 9 . berikut:

Tabel 9. Output SPSS Koefisien Korelasi $X_{3}$ atas $X_{1}$

\begin{tabular}{|c|c|c|c|c|}
\hline \multicolumn{5}{|c|}{ Correlations } \\
\hline & & & Personality & ES \\
\hline \multirow{3}{*}{$\begin{array}{l}\text { Pearson } \\
\text { Correlation }\end{array}$} & REB & 1.000 & .582 & .309 \\
\hline & Personality & .582 & 1.000 & .495 \\
\hline & ES & .309 & .495 & 1.000 \\
\hline \multirow{3}{*}{ Sig. (1-tailed) } & REB & . & .000 & .003 \\
\hline & Personality & .000 & . & .000 \\
\hline & ES & .003 & .000 & \\
\hline \multirow{3}{*}{$\mathrm{N}$} & REB & 79 & 79 & 79 \\
\hline & Personality & 79 & 79 & 79 \\
\hline & ES & 79 & 79 & 79 \\
\hline
\end{tabular}


Tahap selanjutnya setelah melakukan uji signifikansi dan linearitas persamaan regresi serta pengujian koefiseien korelasi yaitu pengujian analisis jalur (path analysis). Hasil uji analisis jalur (path analysis) adalah sebagai berikut:

\section{a) Environmental Sensitivity $\left(\mathbf{X}_{2}\right)$ atas Personality $\left(\mathbf{X}_{1}\right)$}

Perhitungan koefisien jalur dengan bantuan aplikasi SPSS ver. 20. Hasil perhitungan dapat dilihat pada tabel 10. berikut:

Tabel 10. Output SPSS Koefisien Jalur $X_{2}$ atas $X_{1}$

\begin{tabular}{|c|c|c|c|c|c|c|c|c|c|c|}
\hline \multicolumn{11}{|c|}{ Coefficients $^{\mathrm{a}}$} \\
\hline \multirow{2}{*}{ Model } & \multicolumn{2}{|c|}{$\begin{array}{c}\text { Unstandardized } \\
\text { Coefficients }\end{array}$} & \multirow{2}{*}{$\begin{array}{c}\begin{array}{c}\text { Standardized } \\
\text { Coefficients }\end{array} \\
\text { Beta }\end{array}$} & \multirow{2}{*}{$\mathrm{t}$} & \multirow{2}{*}{ Sig. } & \multicolumn{2}{|c|}{$\begin{array}{l}95.0 \% \text { Confidence } \\
\text { Interval for B }\end{array}$} & \multicolumn{3}{|c|}{ Corr elations } \\
\hline & B & $\begin{array}{l}\text { Std. } \\
\text { Error }\end{array}$ & & & & $\begin{array}{l}\text { Lower } \\
\text { Bound }\end{array}$ & $\begin{array}{l}\text { Upper } \\
\text { Bound }\end{array}$ & $\begin{array}{l}\text { Zero- } \\
\text { order }\end{array}$ & Partial & Part \\
\hline (Constant) & 71.386 & 7.606 & & 9.385 & .000 & 56.240 & 86.532 & & & \\
\hline Personality & .477 & .095 & .495 & 4.993 & .000 & .287 & .667 & .495 & .495 & .495 \\
\hline
\end{tabular}

Dari hasil perhitungan analisis jalur (path analysis) $\mathrm{X}_{2}$ atas $\mathrm{X}_{1}$ diperoleh hasil $\mathrm{Phi}_{21}$ sebesar 0.495 dengan t-hitung $=4.993>\mathrm{t}_{\text {-tabel }}(0.01 ; 77)=2.3758$, yang artinya terdapat pengaruh langsung antara personality terhadap environmental sensitivity yang signifikan. Dengan demikian dapat disimpulkan bahwa meningkatnya personality mengakibatkan peningkatan environmental sensitivity yang signifikan.

\section{b) Responsible Environmental Behavior $\left(\mathrm{X}_{3}\right)$ atas Personality $\left(\mathrm{X}_{1}\right)$ dan Enviromental Sensitivity $\left(\mathbf{X}_{2}\right)$}

Perhitungan koefisien jalur dengan bantuan aplikasi SPSS ver. 20. Hasil perhitungan dapat dilihat pada tabel 11. berikut: 
Tabel 11. Output SPSS Koefisien Jalur $X_{3} \operatorname{atas} X_{1}$ dan $X_{2}$

\begin{tabular}{|c|c|c|c|c|c|c|c|c|c|c|c|}
\hline \multicolumn{12}{|c|}{ Coefficients ${ }^{\mathrm{a}}$} \\
\hline \multirow{2}{*}{\multicolumn{2}{|c|}{ Model }} & \multicolumn{2}{|c|}{$\begin{array}{c}\text { Unstandardized } \\
\text { Coefficients }\end{array}$} & \multirow{2}{*}{$\begin{array}{c}\text { Standardized } \\
\text { Coefficients } \\
\text { Beta }\end{array}$} & \multirow[t]{2}{*}{$\mathrm{T}$} & \multirow[t]{2}{*}{ Sig. } & \multicolumn{2}{|c|}{$\begin{array}{l}95.0 \% \text { Confidence } \\
\text { Interval for B }\end{array}$} & \multicolumn{3}{|c|}{ Correlations } \\
\hline & & B & $\begin{array}{l}\text { Std. } \\
\text { Error }\end{array}$ & & & & $\begin{array}{l}\text { Lower } \\
\text { Bound }\end{array}$ & $\begin{array}{l}\text { Upper } \\
\text { Bound }\end{array}$ & $\begin{array}{l}\text { Zero- } \\
\text { order }\end{array}$ & Partial & Part \\
\hline & (Constant) & 26.147 & 9.768 & & 2.677 & .009 & 6.694 & 45.601 & & & \\
\hline 1 & Personality & .510 & .096 & .568 & 5.297 & .000 & .318 & .702 & .582 & .519 & .494 \\
\hline & ES & .026 & .100 & .028 & 261 & .795 & -.173 & .225 & .309 & .030 & .024 \\
\hline
\end{tabular}

Dari hasil perhitungan analisis jalur (path analysis) $\mathrm{X}_{3}$ atas $\mathrm{X}_{2}$ diperoleh hasil $\mathrm{Phi}_{32}$ sebesar 0.028 dengan thitung $=0.261<\operatorname{ttabel}_{(0.01 ; 77)} 2.3758$, yang artinya terdapat pengaruh langsung antara environmental sensitivity terhadap responsible environmental behavior namun tidak signifikan dan perhitungan analisis jalur (path analysis) $\mathrm{X}_{3}$ atas $\mathrm{X}_{1}$ diperoleh hasil $\mathrm{Phi}_{31}$ sebesar 0.568 dengan thitung $=5.297>\operatorname{ttabel}_{(0.01 ; 77)}=2.3758$, yang artinya terdapat pengaruh langsung antara personality terhadap responsible environmental behavior yang signifikan. Dengan demikian dapat disimpulkan bahwa meningkatnya environmental sensitivity mengakibatkan peningkatan responsible environmental behavior yang signifikan dan meningkatnya personality juga mengakibatkan peningkatan responsible environmental behavior meskipun tidak signifikan.

\section{c) Responsible Environmental Behavior $\left(\mathrm{X}_{3}\right)$ atas Personality $\left(\mathrm{X}_{1}\right)$ melalui \\ Environmental Sensitivity $\left(\mathbf{X}_{2}\right)$}

Pengaruh variabel personality terhadap variabel responsible environmental behavior melalui variabel environmental sensitiviry dapat diperoleh dengan menggunakan rumus sebagai berikut :

$$
\mathrm{Phi}_{31.2}=\left(\mathrm{Phi}_{21}\right)\left(\mathrm{Phi}_{32}\right)
$$


Nilai koefisien jalur $X_{2}$ atas $X_{1}$ yaitu sebesar 0.495 dengan thitung $=4.993>$ $\operatorname{ttabel}_{(0.01 ; 77)}=2.3758$, yang artinya terdapat pengaruh langsung antara personality terhadap environmental senditivity secara signifikan. Tetapi nilai koefisien jalur $\mathrm{X}_{3}$ atas $\mathrm{X}_{2}$ yaitu sebesar 0.028 dengan rthitung $=0.261<\operatorname{tabel}_{(0.01 ; 77)}=2.3758$, yang artinya terdapat pengaruh langsung antara environmental sensitivity terhadap responsible environmental behavior namun tidak signifikan, maka nilai koefisien jalur $\mathrm{X}_{3}$ atas $\mathrm{X}_{1}$ melalui $\mathrm{X}_{2}$ tidak dapat dihitung. Dengan demikian dapat disimpulkan bahwa meningkatnya personality hanya dapat meningkatkan responsible environmental behavior secara langsung, tetapi personality tidak dapat meningkatkan responsible environmental behavior secara tidak langsung melalui meningkatnya environmental sensitivity.

Berdasarkan hasil pengujian hipotesis dapat diketahui bahwa variasi personality dapat mempengaruhi environmental sensitivity dan responsible environmental behavior yang dimiliki siswa, serta variasi environmental sensitivity dapat mempengaruhi responsible environmental behavior siswa meskipun tidak signifikan. Hasil penelitian ini sesuai dengan penelitian yang dilakukan sebelumnya oleh Ananda (2018) yaitu bahwa terdapat perbedaan environmental sensitivity yang signifikan antara individu yang memiliki personality most accurate dengan siswa yang memiliki personality less accurate. Artinya environmental sensitivity seorang siswa sangat bergantung pada personality yang dimilikinya. Personality siswa perempuan dan laki-laki tidak begitu signifikan berbeda dalam hal implementasinya dalam bertindak (Putrawan, 2013).

Model Hines (2010) menjelaskan bahwa faktor-faktor yang dapat mempengaruhi responsible environmental behavior yaitu faktor personality, keinginan untuk bertindak, dan faktor situasional. Salah satu faktor situasional yang dapat mempengaruhi responsible environmental behavior yaitu environmental sensitivity (Hines, Hungerford \& Tomera, 2010).

Penelitian sebelumnya mengenai kontribusi relatif dari delapan variabel dalam memprediksi responsible environmental behavior. Kedelapan variabel tersebut adalah (1) level of environmental sensitivity, (2) perceived knowledge of environmental action strategies, (3) perceived skill in using environmental action strategies, (4) psychological sex role classification, (5) individual locus of control, (6) group locus of control, (7) attitude toward pollution dan (8) belief in technology. Hasil penelitian menunjukkan bahwa tujuh dari delapan variabel ditemukan signifikan secara statistik, dan satu variabel yaitu belief in technology didapatkan hasil yang tidak signifikan terdahap responsible environmental 
behavior. Hasil menunjukkan bahwa prediktor terbaik untuk semua responden adalah variabel 1, 2, dan 3 yang disebutkan di atas. Hasil ini menunjukan bahwa environmental sensitivity merupakan salah satu variabel penting yang dapat mempengaruhi responsible environmental behavior (Sia, Hungerford \& Tomera, 1986)

Model Hungerford and Volk (2013) yaitu menjelaskan bahwa environmental sensitivity merupakan salah satu faktor penting yang berperan sebagai variabel prasyarat yaitu berupa entry level variable dalam membentuk responsible environmental behavior, tetapi hasil penelitian menunjukan bahwa pengaruh environmental sensitivity terhadap responsible environmental behavior itu tidak signifikan, sehingga environmental sensitivity tidak cocok dijadikan sebagai variabel mediator antara personality dan responsible environmental behavior.

Hasil penelitian memberikan informasi baru yang dapat dikembangakan untuk diteliti selanjutnya, karena seharusnya menurut beberapa ahli salah satunya adalah Chawla (2010) mengemukakan bahwa environmental sensitivity merupakan variabel yang sangat penting yang dapat mempengaruhi responsible environmental behavior. Environmental sensitivity telah menjadi subjek dari badan penelitian kualitatif yang sedang berkembang, dimana sensitivitas dikaitkan dengan jenis-jenis khusus pengalaman hidup yang signifikan.

Personality dan environmental sensitivity dapat menjadi suatu faktor responsible environmental behavior siswa karena suatu perilaku salah satunya responsible environmental behavior dapat terbentuk dalam diri siswa sesuai dengan sifat, karakter dan jati diri atau kepribadian (personality) yang dimilikinya. Empati siswa terhadap masalah lingkungan yang adapun dapat memunculkan responsible environmental behavior karena secara alamiah seorang individu ingin mencoba untuk menyelesaikan permasalahan salah satunya adalah masalah lingkungan dengan memulai dirinya sendiri untuk berperilaku bertanggung jawab terhadap lingkungan (responsible environmental behavior). Sensitivitas lingkungan (environmental sensitivity) tidak cocok sebagai variabel mediator antara personality dengan responsible environmental behavior karena siswa yang memiliki personality tinggi sudah cukup untuk dapat berperilaku tanggung jawab terhadap lingkungan (responsible environmental behavior).

\section{KESIMPULAN}

Beberapa temuan dalam penelitian ini adalah sebagai berikut : 
1) Personality berpengaruh langsung terhadap responsible environmental behavior secara signifikan

2) Personality berpengaruh langsung terhadap environmental sensitivity secara signifikan

3) Environmental sensitivity berpengaruh langsung tetapi tidak signifikan terhadap responsible environmental behavior

4) Environmental sensitivity tidak cocok sebagai mediator variabel antara Personality dengan responsible environmental behavior

Berdasarkan temuan-temuan tersebut dapat disimpulkan bahwa variasi personality dan environmental sensitivity dapat mempengaruhi responsible environmental behavior siswa. Setiap siswa dapat memiliki responsible environmental behavior sesuai dengan personality dan environmental sensitivity yang dimilikinya. Environmental sensitivity berpengaruh langsung tetapi tidak signifikan terhadap responsible environmental behavior, sehingga environmental sensitivity tidak cocok sebagai mediator variabel antara personality dengan responsible environmental behavior.

\section{DAFTAR PUSTAKA}

Ananda, R. (2018). Analisis Komparatif Mengenai Sensitifitas Lingkungan Didasarkan Pada Kecerdasan Naturalis Dan Kepribadian. Thesis, UNJ.

Chawla, L. (2010). Significant Life Experiences Revisited: A Review of Research on Sources of Environmental Sensitivity. The Journal of Environmental Educatoion, 29(3), 37-41. https://doi.org/10.1080/00958969809599114

Dunlap, R. E. and Van Liere K. D. (1984). Commitment to the dominantsocial paradigm and concern for environmental quality. Oklahoma State University: Social Sci. Q.

Handriana, T., \& Ambara, R. (2016). Responsible Environmental Behavior Intention Of Travelers On, 22(2), 135-150.

Hines, J. M., Hungerford, H. R., \& Tomera, A. N. (2010). Analysis and Synthesis o f Research on Responsible Environmental Behavior: A Meta-Analysis. The Journal of Environmental Educartion, 18(2), 37-41. https://doi.org/http://dx.doi.org/10.1080/00958964.1987.9943482

Hungerford, H. R., \& Volk, T. L. (2013). Changing Learner Behavior Through Environntental Education, (May 2015), 37-41. https://doi.org/10.1080/00958964.1990.10753743

Id, S. P., Chou, J., Morrison, A. M., \& Lin, M. (2018). Will the Future Be Greener? The Environmental Behavioral Intentions of University Tourism Students. Sustainability, (1), 1-17. https://doi.org/10.3390/su10030634 
Krajhanzl, J. (2010). Environmental And Proenvironmental Behavior. Health Education: International Experiences, 251-274.

Laraga, R. (2017). Pengaruh Personality dan Gender Terhadap Wawasan Lingkungan. Jurnal Ilmu Administrasi, 6, 41-48.

McCrae, R. R., Costa, P. T. Jr. (2009). The Five-Factor Model of personality traits: consensus and controversy. In P. L. Corr and G. Matthews (eds.). Cambridge: Cambridge University Press.

Nadiroh, R. A. (2011). Environmental Sensitivity Dan Hubungannya Dengan Perilaku Pelestarian Kearifan Lokal. Jurnal Pendidikan Usia Dini, 251-265. https://doi.org/https://doi.org/10.21009/JPUD.112

Putrawan, I Made. (2013). Measuring Teachers Personality by Applying "Big Five Personality" Based on Teachers Gender and School Level: A Comparative Analysis. Comparative Education Bulletin. 15(1), 2013, 60-75.

Ramsey, J., Hungerford, H. R., Tomera, A.N. (1981). The effects of environmental action and environmental case study instruction on the overt environmental behavior of eighthgrade students. Journal of Environmental Education, 24-30.

Sia, A. P., Hungerford, H. R., \& Tomera, A. N. (2010). Selected Predictors of Responsible Environmental Behavior: An Analysis. The Journal of Environmental Education, 17(2), 31-40.

Sivek, D. J. and Hungerford, H. (2014). Predictors of Responsible Behavior in Members of Three Wisconsin Conservation Organizations. The Journal of Environmental Education. 21(2), 35-40. 